\title{
Histopathological Survey on Sarcocystis Species Infection in Slaughtered Cattle of Zabol-Iran
}

\author{
Zabol-İran'da Kesilen Siğırlarda Sarcocystis Türlerinin Yol Açtı̆̆ \\ Enfeksiyonlar Üzerine Histopatolojik İnceleme
}

\author{
(1) Ehsan Faghiri, (1) Aida Davari, (1) Reza Nabavi
}

University of Zabol Faculty of Medicine, Department of Pathobiology, Zabol, Iran

\author{
Cite this article as: Faghiri , Davari A, Nabavi R. Histopathological Survey on Sarcocystis Species Infection in Slaughtered \\ Cattle of Zabol-Iran. Turkiye Parazitol Derg 2019;43(4):182-6.
}

\begin{abstract}
Objective: Sarcocystosis is an important zoonotic protozoal disease with worldwide distribution and wide range of hosts. The aim of the present study was to determine the intensity of Sarcocystis spp. infection and to show histopathological features of their cystic lesions in slaughtered cattle of Zabol- Iran.

Methods: From April to September 2018, 500 tissue samples from esophagus, heart, diaphragm, tongue and masticatory muscles were prepared from 100 slaughtered cattle. All samples were fixed in $10 \%$ neutral buffered formalin and routine tissue processing protocol was performed.

Results: The microscopic results showed that $92.2 \%$ of specimens had thin-walled cysts of $S$. cruzi and $14 \%$ had thick-walled Sarcocystis (S. hirsuta and S. hominis) but macrocyst was only observed in one cattle. The positivity rate of thin walled cysts was $58.8 \%$ for heart, $13.9 \%$ for masticatory muscles, $10.2 \%$ for tongue, $9.3 \%$ for esophagus and $7.8 \%$ for diaphragm. The positivity rate of thick walled cysts was $32.8 \%$ for esophagus, $28.6 \%$ for tongue, $22.9 \%$ for heart, $15.7 \%$ for masticatory muscles and $0 \%$ for diaphragm, which could represent either S. hominis or S. hirsuta. The most infected tissue was heart and the least infected tissue was diaphragm. Thin walled cysts (S. cruzi) were mostly found in heart and were less found in diaphragm. However, thick-walled cysts (S. hirsuta and S. hominis) were mostly detected in esophagus. No thick-walled cysts were found in diaphragm muscle

Conclusion: A high positivity rate of sarcocystosis in slaughtered cattle in Zabol abattoir revealed heavily environmental contamination of Sistan region by this important parasitic disease.
\end{abstract}

Keywords: Cattle, sarcocystosis, thin-walled cyst, thick-walled cyst

Öz

Amaç: Sarkosistozis, dünya çapında yaygın bir dağılıma sahip ve çok çeşitli konakları olan önemli bir zoonotik protozoal hastalıktır. Bu çalışmanın amacı; Zabol-İran'da kesilen sığırlarda Sarkosistis spp. enfeksiyonunun yoğunluğunu belirlemek ve sarkosistis kistik lezyonlarının histopatolojik özellikleri göstermektir.

Yöntemler: Nisan-Eylül 2018 tarihleri arasında kesilen 100 sığırın özofagus, kalp, diyafram, dil ve çiğneme kaslarından 500 doku örneği hazırlanmıştır. Tüm numuneler \%10 nötr tamponlu formalin ile sabitlenmiştir ve tüm numunelere rutin doku işleme protokolü uygulanmıştır.

Bulgular: Mikroskobik sonuçlar, örneklerin \%92,2'sinde S. cruzi'nin ince duvarlı kistleri, \%14'ünde kalın duvarlı Sarkosistis (S. hirsuta ve $S$. hominis) olduğunu, ancak makrokistin sadece bir sığırda görüldüğünü göstermiştir. İnce duvarlı kistlerin pozitiflik oranı kalp için \%58,8, çiğneme kasları için \%13,9, dil için \%10,2, özofagus için \%9,3 ve diyafram için \%7,8 idi. S. hominis ve $S$. hirsuta'yı temsil edecek şekilde kalın duvarlı kistlerin pozitiflik oranı özofagus için \%32,8, dil için \%28,6, kalp için \%22,9, çiğneme kasları için \%15,7 ve diyafram için \%0 idi. En çok enfekte olan doku kalp ve en az enfekte olan doku diyaframdı. İnce duvarlı kistler (S. cruzi) çoğunlukla kalpte bulundu ve diyaframda en az bulundu. Ancak, özofagusta kalın duvarlı kistler (S. hirsuta ve S. hominis) tespit edildi. Diyafram kasında kalın duvarlı kist bulunmadı.

Sonuç: Zabol mezbahasında kesilen sığırlarda sarkosistosisin yüksek pozitiflik oranı, Sistan bölgesinin bu önemli paraziter hastalıkla ağır çevresel kontaminasyonunu ortaya çıkarmaktadır.

Anahtar Kelimeler: Sığır, sarkosistosis, ince duvarlı kist, kalın duvarlı kist

Received/Geliş Tarihi: 02.07.2019 Accepted/Kabul Tarihi: 26.08.2019

Address for Correspondence/Yazar Adresi: Aida Davari MD, University of Zabol Faculty of Medicine, Department of Pathobiology, Zabol, Iran Phone/Tel: +98 5434822253 E-mail/E-Posta: davari.aida1@gmail.com ORCID ID: orcid.org/0000-0001-5598-4172 


\section{INTRODUCTION}

Sarcocystosis is an important protozoan intracellular parasitic disease with global distribution in broad range of wild and domestic animal species as well as humans (1). Sarcocystis spp. have obligatory two-host life cycle and cause muscle cysts formation by merogony stage in herbivorous mammals (such as cattle, buffaloes, sheep and pigs) as intermediate hosts. Besides, sporogony and gamogony stages take place in carnivores and humans (by consumption of undercooked meat) as definitive hosts $(2,3)$. In previous researches, three species of Sarcocystis have been reported in cattle: $S$. cruzi, S. hirsuta, and S. hominis, with canids, felids, and primates, as definitive hosts, respectively. Among these, $S$. cruzi with more than $90 \%$ prevalence in adult cattle cardiac muscle has the most occurrence reports in many countries in the world (4). S. hirsuta and S. hominis with less infection rates in comparison with $S$. cruzi, mostly have been found in esophagus and striated muscles (but less in cardiac muscle) (3,5); however, epidemiological reports have been scarce in the last few years. In Iran, there are only two reports about the occurrence of macroscopic type of sarcocystosis in cattle ( $S$. hirsuta) $(5,6)$.

Identification of Sarcocystis spp. is complicated. Although, molecular methods are insufficiently convenient for species identifications because of high genetic similarity; the ultrastructure observation of primary cyst wall technique is considered to be one possible reliable method for identifying Sarcocystis spp $(6,7)$.

Based on the reports from different provinces of Iran, infection rate of sarcocystosis in adult bovine muscles is absolutely high (8-15), but there is no information about intensity of this parasitic disease in Sistan region. So, the present research aims to determine the intensity of infection and histopathological investigation of Sarcocystis spp. cystic lesions in slaughtered cattle of Zabol abattoir.

\section{METHODS}

\section{Collection of Samples}

From April to September 2018, 100 slaughtered cattle in Zabol industrial slaughterhouse were randomly examined for the presence of Sarcocystis macroscopically and microscopically. A total of 500 tissue samples with the size of $1 \times 1 \times 0.5 \mathrm{~cm}$ from esophagus, heart, diaphragm, tongue and masticatory muscles of these cattle were obtained.

This manuscript was conducted on slaughtered cattle and does not contain clinical or experimental studies and patient data.

\section{Microscopic Examination}

All specimens were fixed in $10 \%$ neutral buffered formalin for 24 hours, then embedded in paraffin, sectioned at $5 \mu \mathrm{m}$ with microtome, stained with hematoxylin and eosin staining according to routine protocol and finally submitted to light microscopy for examination of Sarcocystis spp. cystic lesions. Considering to the histologically differences of the wall thickness of $S$. cruzi (thin-walled sarcocyst) and S. hirsuta, or S. hominis (thick-walled sarcocyst), the found cysts were counted under light microscope and their wall thickness was measured by micrometry method using ocular micrometer (micro-scale).

\section{Statistical Analysis}

For statistical evaluation, data analysis was performed using SPSS version 20 (SPSS Inc., Chicago, IL, USA), and chi-square test. Significance level was considered as $\mathrm{p}<0.05$.

\section{RESULTS}

Out of 100 cattle examined, only one cattle (1\%) showed macroscopic type of Sarcocystis spp. In this case, numerous milky-white colored spindle-shaped macrocysts of $S$. hirsuta were observed in the tunica muscularis of masticatory muscle (Figure 1). In microscopic evaluation, spherical shape cysts with a mean $14 \mu$ in diameter impacted with bradyzoites were observed. The cysts wall thickness was more than $2 \mu$ (Figure 2). Totally, 531 cysts were observed in 500 tissue samples and all 100 cattle (100\%) were involved with Sarcocystis spp. at least in one of their organs, histologically. Thin-walled Sarcocystis corresponding with S. cruzi were found in $92.2 \%$ of specimens, while $14 \%$ had thickwalled cysts (S. hirsuta or S. hominis). The distribution of thinwalled and thick-walled microscopic cysts in different muscles of cattle is summarized in Table 1 . The chi-square test showed significant differences between frequencies of Sarcocystis in different muscles $(\mathrm{p}<0.001)$. The highest incidence of thin-walled cysts (S. cruzi) was in heart muscles, whereas thick-walled cysts (S. hirsuta and S. hominis) were mostly observed in the esophagus. In addition, thin-walled sarcocysts have a lower frequency (7.8\%) in the diaphragm muscle compared to other muscles.

In histopathological examination, the different shapes of microcysts (spherical, oval or elongated) with thin or thick

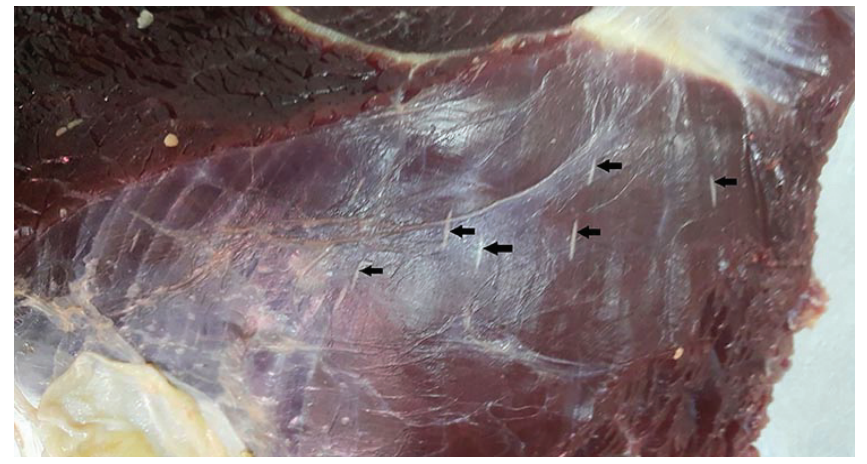

Figure 1. Masticatory muscle of cattle showing multiple macrosarcocysts (S. hirsuta), in the tunica muscularis (arrows)

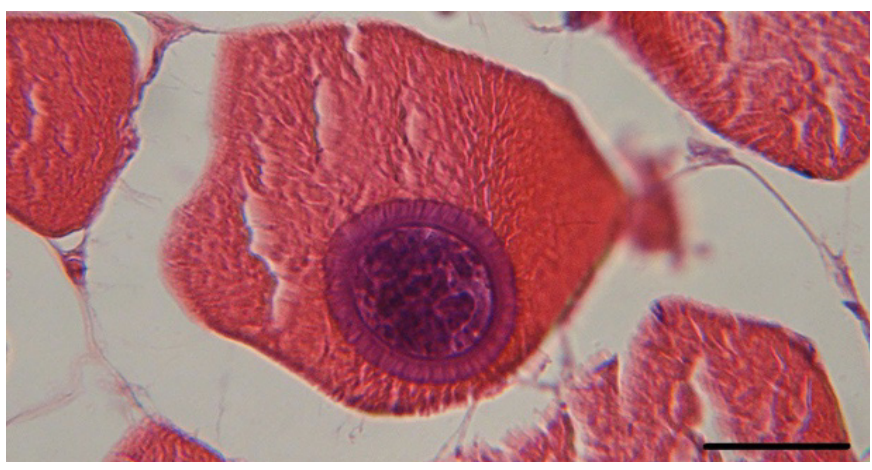

Figure 2. Microscopic section of masseter muscle of the cattle showing round shape thick-walled (more than $2 \mu \mathrm{m}$ ) sarcocyst (S. hirsuta or S. hominis) (H\&E, scale bar=35 $\mu \mathrm{m}$ ) 
distinct walls were observed in over mentioned muscles but no inflammatory reaction was found around the cysts or surround the infected muscle fibers (Figures 3-5).

\section{DISCUSSION}

Sarcocystosis is an important zoonotic disease with economic impact and worldwide distribution in various animal species and human being. Many considerable researches have been conducted about the importance and prevalence of this disease in different intermediate hosts and various countries (1,2,16-21). Although, there are many reports of sarcocystosis occurrence in domestic animals (especially cattle) in Iran $(9,10,13-15)$, but most studies have not attempted to identify the species of the parasite in cattle. Moreover, considering the popularity of cattle meat consumption in Sistan region, up to now, there has not been any study about intensity of this disease in Zabol city.

In histopathological investigation, thin-walled sarcocysts $(<1 \mu \mathrm{m})$ identify as $S$. cruzi and Thick-walled sarcocysts $(2-7 \mu \mathrm{m})$ identify as $S$. hirsuta or $S$. hominis using micrometry method $(3,22)$. Based on the abovementioned method, the results of the present study revealed that all cattle and all tissue samples were infected with Sarcocystis spp. (92.2\% of tissue samples with S. cruzi and $14 \%$ with $S$. hirsuta or S. hominis). These findings are in accordance to some investigations which have found in other countries: $100 \%$ in Brazil (23), $100 \%$ in Argentina (4), $100 \%$ in the United States (3), $97.4 \%$ in Belgium (24), $97.8 \%$ in Iraq (25) and $93.4 \%$ in

Table 1. Distribution of thin-walled and thick-walled microscopic sarcocysts in different muscles of cattle slaughtered in Zabol abattoir

\begin{tabular}{|l|l|l|l|}
\cline { 1 - 2 } Type of muscle & $\begin{array}{l}\text { Thick-walled } \\
\text { sarcocyst }\end{array}$ & $\begin{array}{l}\text { Thin-walled } \\
\text { sarcocyst }\end{array}$ & $\begin{array}{l}\text { Total } \\
\text { number } \\
\text { (\%) }\end{array}$ \\
\hline & Number (\%) & Number (\%) & $287(54 \%)$ \\
\hline Heart & $16(22.9 \%)$ & $271(58.8 \%)$ & $27(12.6 \%)$ \\
\hline Esophue & $20(28.6 \%)$ & $47(10.2 \%)$ & $66(12.4 \%)$ \\
\hline Diaphragm & $23(32.8 \%)$ & $43(9.3 \%)$ & $36(6.8 \%)$ \\
\hline Masseter & $0(0 \%)$ & $36(7.8 \%)$ & $75(14.1 \%)$ \\
\hline Total number (\%) & $70(100 \%)$ & $461(100 \%)$ & $531(100 \%)$ \\
\hline The percentages have been prepared columnar & $64(13.9 \%)$ & \\
\hline
\end{tabular}

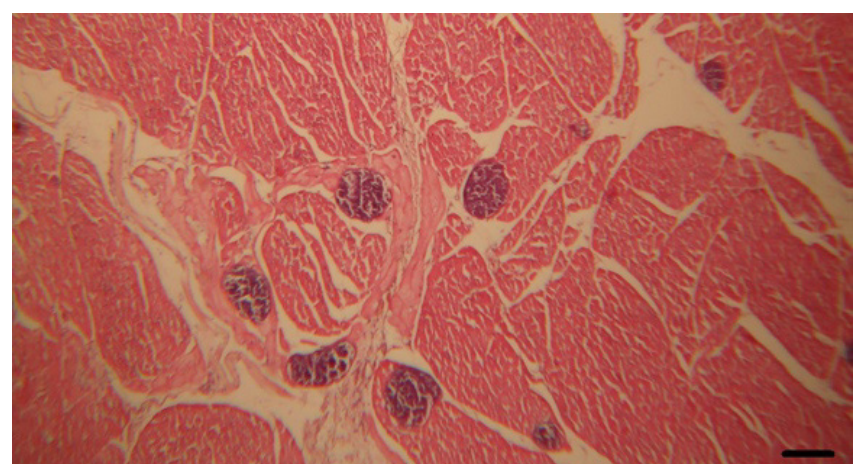

Figure 3. Cardiac muscle of a cattle showing multiple large round and oval shape thin-walled (less than $1 \mu \mathrm{m}$ ) sarcocysts (S. cruzi) around the purkinje cells without any tissue reactions (H\&E, scale bar $=130 \mu \mathrm{m}$ )
Turkey (Iran border countries) (26). Whereas, the infection rate in the present study is considerable higher than Egypt, 7.45 (20), Malaysia, 36.2\% (2), Philippines, 55\% (27) and Ethiopia 82\% (28). Besides, in comparison to other areas of Iran, the frequency of sarcocystosis in cattle in the present study (100\%) is consistent with Shiraz, 100\% (9), Kerman, 100\% (11), Hamadan, 100\% (14), Bojnurd, 100\% (13), Tabriz, 100\% (5), Ahvaz, 100\% (15) and higher than Isfahan, 89\% (12), Shahrekord, 91\% (10) and Karaj, $96 / 8 \%$ (29). Aforementioned researches which are conducted in various parts of Iran demonstrate that cattle contamination to Sarcocystis spp. is notable. The first detection of macroscopic type of sarcocystosis in cattle ( $S$. hirsuta) in Iran was reported by Shekarforoush et al. (6). In this case report, several spindleshaped macrocysts were observed in diaphragmatic muscle. In a related study, the incidence of macroscopic sarcocysts in cattle slaughtered in Tabriz was declared $8.2 \%$, predominantly in esophagus muscle (5).

In the present study macro-sarcocysts in cattle ( $S$. hirsuta) were observed in one case (1\%) and in the masticatory muscle. In this study the shape and size of macrocysts were come in agree with over mentioned studies. In other studies, in Iran, no macroscopic cysts were found in cattle which were examined for Sarcocystis infection $(11-14,17,29)$. The results of the microscopic examination in the current study revealed that the frequency of thin-walled sarcocysts (S. cruzi) and thick-walled sarcocysts (S. hirsuta or S. hominis) were $92.2 \%$ and $14 \%$, respectively and all cattle were infected with sarcocystosis at least in one of their organs. The most infected tissue was cardiac muscle (58.8\% for thin-walled cysts) and esophagus (32.8\% for thick-

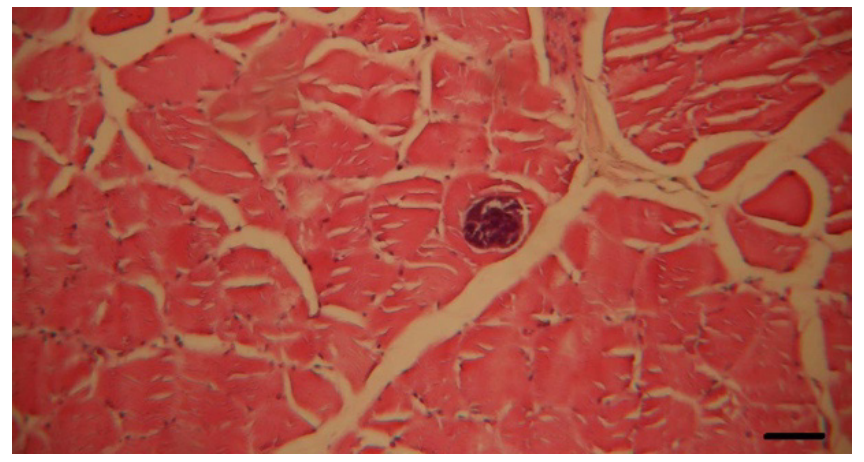

Figure 4. Spherical shape thin-walled (less than $1 \mu \mathrm{m}$ ) sarcocyst (S. cruzi) in the esophagus of cattle. The cyst initiated no inflammatory reaction ( $\mathrm{H} \& \mathrm{E}$, scale bar $=70 \mu \mathrm{m})$

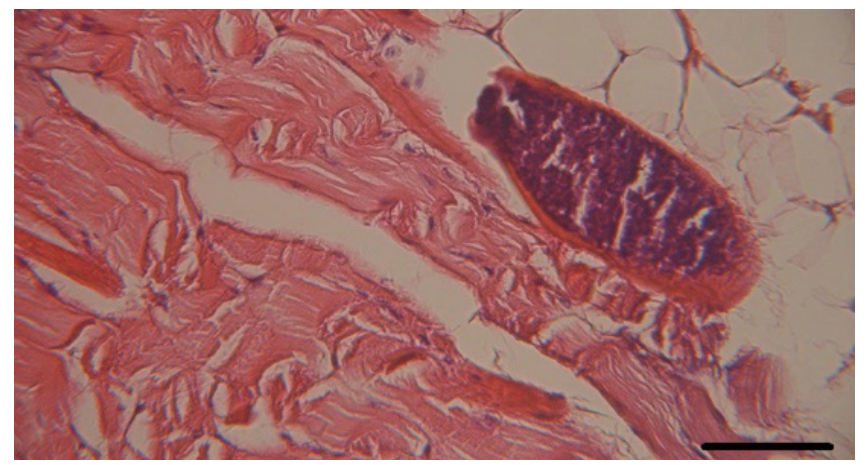

Figure 5. Elongated thin-walled $(1 \mu \mathrm{m})$ sarcocyst (S. cruzi) in the tongue muscle of cattle. The cyst initiated no inflammatory reaction $(\mathrm{H} \& \mathrm{E}$, scale bar $=90 \mu \mathrm{m})$ 
walled cysts) and the less was diaphragm (for both of thin and thick-walled cysts, $7.8 \%$ and $0 \%$ respectively). According to these findings, previous researches have demonstrated that $S$. cruzi is predominantly occurred in cardiac muscle $(23,29,30)$. The frequency of thick-walled sarcocysts in the present study (14\%) is lower than two other studies $(12,29), 21 \%$ and $34 / 4 \%$, respectively. Additionally, opposite to the results of Nourollahi Fard et al. (29) which reported that thick-walled sarcocyst mostly were detected in diaphragm, in our study diaphragm showed no thick-walled cyst. It seems useful to do accurate recognition of $S$. hirsuta and S. hominis thick-walled cyst but it was not possible for us considering some problems in ultrastructure observation of primary cysts wall via electron microscopy which is too expensive and difficult to access (30).

In present histopathological investigation, opposite to some studies which reported the existence of inflammatory reactions around some sarcocysts continuing to degeneration $(18,21,29)$, no inflammatory reaction was found.

\section{CONCLUSION}

The results of present study demonstrate high frequency of $S$. cruzi in comparison with low frequency of S. hirsuta and $S$. hominis. Considering to this fact that the Sarcocystis parasite can cause economic losses in livestock animals and could be a threat to the human community health, future investigation about parasite phylogeny and prevention procedures seems to be useful.

\section{Acknowledgements}

The authors gratefully acknowledge the University of Zabol for financial support as well as the Mohammad Abad industrial slaughterhouse for their excellent cooperation.

\section{* Ethics}

Ethics Committee Approval: This manuscript was conducted on slaughtered cattle and does not contain clinical or experimental studies and patient data.

Informed Consent: This manuscript was conducted on slaughtered cattle and does not contain clinical or experimental studies and patient data.

Peer-review: Internally peer-reviewed.

\section{* Authorship Contributions}

Concept: E.F., A.D., R.N., Design: E.F., A.D., R.N., Data Collection or Processing: E.F., A.D., R.N., Analysis or Interpretation: E.F., A.D., R.N., Literature Search: E.F., A.D., R.N., Writing: E.F., A.D., R.N.

Conflict of Interest: The authors declare that they have no conflict of interest.

Financial Disclosure: University of Zabol (Grant number: UOZ_GR_9517_87)

\section{REFERENCES}

1. Hosseini SR, Shakerian A, Tahamtan N. Survey of Sarcocystis infection in slaughtered sheep in Isfahan, Qom and Shahre-Kord, Iran. J Anim Vet Adv 2012;11:2683-6.

2. Latif B, Vellayan S, Heo CC, Al-Bayati SM, Al-Amiry AM. High prevalence of muscular sarcocystosis in cattle and water buffaloes from Selangor, Malaysia. Trop Biomed 2013;30:699-705.
3. Fayer R, Esposito DH, Dubey JP. Human infections with Sarcocystis species. Clin Microbiol Rev 2015;28:295-311.

4. More G, Basso W, Bacigalupe D, Venturini MC, Venturini L. Diagnosis of Sarcocystis cruzi, Neospora caninum, and Toxoplasma gondii infections in cattle. J Parasitol Res 2008;102:671-5.

5. Mirzaei M, Rezaei, H. A survey on Sarcocystis spp. infection in cattle of Tabriz city, Iran. J Parasit Dis 2016;40:648-51.

6. Shekarforoush SS, Razavi SM, Abbasvali M. First detection of Sarcocystis hirsuta from cattle in Iran. IJVR 2013;14:155-7.

7. Dubey JP, Speer CA, Fayer R. Sarcocystosis of Animals and Man. 2nd ed. Boca Raton, Florida, USA: CRC Press; 1989.

8. Hamidinejat H, Raz Jalali MH, Nabavi L. Survey on Sarcocystis infection in slaughtered cattle in south-west of Iran, emphasized on evaluation of muscle squash in comparison with digestion method. J Anim Vet Adv 2010;9:1724-6.

9. Shekarforoush SS, Razavi SM, Ahmadi H, Sarihi K. Study on prevalence of Sarcocystis in slaughtered cattle in Shiraz. JVR 2004;59:33-7.

10. Bonyadian M, Meshki B. Study on infestation of cow carcasses to Sarcocyst spp in slaughtered cows in Shahrekord by impression method. Pajouheshva-Sazandegi 2001;19:14-8.

11. Nourollahi Fard SR, Asghari M, Nouri F. Survey of Sarcocystis infection in slaughtered cattle in Kerman, Iran. Trop Anim Health Prod 2009;41:16336.

12. Nourani H, Matin S, Nouri A, Azizi H. Prevalence of thin-walled Sarcocystis cruzi and thick-walled Sarcocystis hirsuta or Sarcocystis hominis from cattle in Iran. Trop Anim Health Prod 2010;42:1225-7.

13. Salehi M, Adinezade A, Mosazade A, Besharati R, Bahari P. The prevalence of Sarcocystis infection in sheep and cattle in Bojnurd, North Khorasan Province, Iran. J Zoonoses 2014;1:60-3.

14. Parandin F, Feizi F, Maghsood AH, Matini M, Roshan A, Fallah MA. Survey on Sarcocystis infection rate in slaughtered cattle and sheep by macroscopic inspection and pepsin digestion methods in Hamadan abattoir, Iran, 2014. Sci J Hamdan Univ Med Sci 2015;22:210-6.

15. Rahdar M, Kardooni T. Molecular identification of Sarcocystis spp. in sheep and cattle by PCR-RFLP from southwest of Iran. Jundishapur J Microbiol 2017;10:e12798.

16. Daryani A, Alaei R, Dehghan MH, Arab R, Sharif M, Ziaei H. Survey of Sarcocystis infection in slaughtered sheep and buffaloes in Ardabil, Iran. J Anim Vet Adv 2006;5:60-2.

17. Shekarforoush SS, Razavi SM, Dehghan SA, Sarihi K. Prevalence of Sarcocystis species in slaughtered goats in Shiraz, Iran. Vet Rec 2005;156:418-20.

18. Valinezhad A, Oryan A, Ahmadi N. Sarcocystis and its complications in camels (Camelus dromedarius) of eastern provinces of Iran. Korean J Parasitol 2008;46:229-34.

19. Farhang-Pajuh F, Yakhchali M, Mardani K. Molecular determination of abundance of infection with Sarcocystis species in slaughtered sheep of Urmia, Iran. Vet Res Forum 2014;5:181-6.

20. Ahmed AM, Elshraway NT, Youssef AI. Survey on Sarcocystis in bovine carcasses slaughtered at the municipal abattoir of El-Kharga, Egypt. Vet World 2016;9:1461-5.

21. Zangana IK, Hussein SN. Prevalence of Sarcocystis species (Sarcocystis ovicanis and Sarcocystis capricanis) in tongue muscle of sheep and goats in Duhok province, Kurdistan region, north Iraq. Sci J Koya Univ 2017;5:3640.

22. Wouda W, Snoep JJ, Dubey JP. Eosinophilic myositis due to Sarcocystis hominis in a beef cow. J Comp Pathol 2006;135:249-53.

23. Silva NRS, Rodrigues RJD, Araujo FAP, Beck C, Olicheski AT. Detection of bovine Sarcocystis cruzi cysts in cardiac muscles: a new technique of concentration for diagnostic. Acta Sci Vet 2002;30:127-9.

24. Vangeel L, Houf K, Chiers K, Vercruysse J, Dherde K, Ducatelle R. Molecular based identification of Sarcocystis hominis in Belgian minced beef. J Food Prot 2007;70:1523-6. 
25. Latif BM, Al-Delemi JK, Mohammed BS, Al-Bayati SM, Al-Amiry AM. Prevalence of Sarcocystis spp. in meat producing animals in Iraq. Vet Parasitol 1999;84:85-90.

26. Kamber U, Arslan MO, Gulbaz G, Tasci GT, Akca A. Identification of Sarcocystis spp. by polymerase chain reaction and microscopic examination in various beef products (minced meat, meatballs, fermented sausage). Turk J Vet Anim Sci 2018;42:1-6.

27. Claveria FG, Petersen B, Macabagdal MR, Farolan RJ, Farrol MA, Gonzalvo F, et al. A survey of bovine, bubaline and swine sarcocystosis in the Philippines. Southeast Asian J Trop Med Public Health 1997;28:173-8.
28. Woldemeskel M, Gebreab F. Prevalence of sarcocysts in livestock of northwest Ethiopia. Zentralbl Veterinarmed B 1996;43:55-8.

29. Nourollahi Fard SR, Kheirandish R, Sattari S. Prevalence and histopathological finding of thin-walled and thick-walled Sarcocysts in slaughtered cattle of Karaj abattoir, Iran. J Parasit Dis 2015;39:272-5.

30. Ghisleni G, Robba S, Germani O, Scanziani E. Identification and prevalence of Sarcocystis spp. cysts in bovine canned meat. Food Control 2006;17:691-4. 